\title{
A Study on Language Learning Strategy Use and Its Relation to Academic Self-concept: The Case of EFL Students in Taiwan
}

\author{
Hui-ju Liu \\ Department of English, Da-Yeh University, Changhua, Taiwan \\ Chih-hui Chang \\ Department of English, Da-Yeh University, Changhua, Taiwan
}

\begin{abstract}
The current study investigates the language learning strategy use (LLSU) among EFL university freshmen and its relation to academic self-concept (ASC). Of six strategy categories, compensation strategies were reported as the most frequently used and social strategies were the least used. Participants with low and medium ASC used compensation strategies the most, while the participants of high ASC used metacognitive strategies the most. A significant positive relationship between strategy use and ASC was identified. All six strategy categories were found to be significant regarding different ASC of the research participants while only three particular strategy items were not. Among the strategy categories, metacognitive and cognitive strategies were found to have the highest correlations with ASC. Among the two components of ASC, academic effort was more highly related to overall strategy use than academic confidence. Educational implications and suggestions from the current study are presented to benefit the promotion of ASC and LLSU.
\end{abstract}

Index Terms-learning strategy use, academic self-concept, strategy category, language learning strategy

\section{INTRODUCTION}

Learning strategies are the conscious thoughts and actions that learners take to achieve their learning goals. Effective learners are able to select learning approaches that suit them better and they also have the competence to orchestrate the strategies that best meet both the task demands and their own learning preferences. Much research has reported the close association between language learning strategy use (LLSU) and various factors including age (Ehrman \& oxford, 1989; Oxford \& Ehrman, 1995; Lan \& Oxford, 2003), gender (Oxford, 1993; Green \& Oxford, 1995), proficiency level (O’Malley \& Chamot, 1990; Chamot, Barnhart, El-Dinary \& Robbins, 1999), and motivation (Ehrman \& Oxford, 1989, 1990; Wharton, 2000). Yet little attention has been given to the relationship between LLSU and academic self-concept (ASC), which is proven to be an important predictor to academic performance (Choi, 2005; Liu, 2008; Muijs, 1997). The current study is, therefore, designed to investigate the relationship between LLSU and ASC and by having an overall understanding of the triangular relationships among LLSU and the two components of ASC, academic confidence and effort, pedagogic implications can be drawn to benefit English language learning. Results from the current study can also provide suggestions for effective language instruction and sustainability of language learners' autonomy.

\section{LITERATURE REVIEW}

\section{A. Language Learning Strategy}

Learning strategies are procedures that facilitate learning tasks (Chamot, 2005), and they also allow learners to become more independent and autonomous lifelong learners (Allwright, 1990; Little, 1991). The importance of language learning strategies (LLSs) is that they are procedures that learners take to manage their own learning and achieve individual desired goals.

Early research into LLSs was concentrated on the establishment of what good LLSs might be (Rubin, 1975; Stern, 1975). Later work by Naiman, Frohlich, Stern, and Todesco (1978), Rubin (1981), and O’Malley, Chamot, StewnerManzanares, Kupper, and Russo (1985) were focused on the identification of good LLSs. Rubin (1981) identified strategies that contribute directly and indirectly to L2 learning. Six direct strategies are: (a) clarification/ verification, (b) monitoring, (c) memorization, (d) guessing/inductive inference, (e) deductive reasoning, and (f) practice; and two indirect strategies are: (a) creating opportunities for practice, and (b) production tricks. Oxford (1990) defines LLSs in general terms as specific methods or techniques used by individual learners to facilitate their comprehension, retention, retrieval and application of information in the second or foreign language.

As well as the various ways of defining LLSs, there are also different approaches of categorizing identified LLSs. O'Malley and Chamot (1990) outlined a scheme including cognitive, metacognitive, and social/affective strategies 
based on research conducted in the 1980s. According to O'Malley and Chamot (1990, pp.44-45), cognitive strategies work with information to enhance learning; metacognitive strategies are higher order executive skills that involve planning, monitoring, or evaluation of a language learning activity, and social/ affective strategies are the interaction with others or control over affect. Oxford (1990, pp.18-21; 2001, pp.167-68) produced a classification system based on much of her previous work, the Strategy Inventory for Language Learning (SILL) and defined six categories of learning strategies are as follows.

(1) Cognitive strategies: processing information and structuring it, e.g. analyzing, summarizing.

(2) Memory strategies: remembering information via making connections between it, e.g. grouping, and using keywords.

(3) Metacognitive strategies: managing the learning process and dealing with the task, e.g. planning, identifying and selecting resources.

(4) Compensation strategies: compensating for knowledge gaps, e.g. guessing, gesturing.

(5) Affective strategies: identifying one's affective traits and knowing how to manage them, e.g. reducing anxiety, encouraging one's self.

(6) Social strategies: learning from and/or with others, e.g. asking for cooperation, working with peers.

Oxford's SILL has been regarded as the most comprehensive classification of LLSs (Ellis, 1994), and it has been used extensively to collect data on large numbers of language learners around the world (see Green \& Oxford, 1995; Park, 1997; Wharton, 2000; Hsiao \& Oxford, 2002; Lan \& Oxford, 2003). Oxford's SILL is a standardized instrument with different versions for language learners of a variety of languages. It has been used to collect data on large numbers of mostly foreign language learners (see Olivares-Cuhat, 2002; Wharton, 2000; Cohen, Weaver \& Li, 1998; Oxford, 1996, 1990; Oxford \& Burry-Stock, 1995; Nyikos \& Oxford, 1993). It has also been employed in studies that correlate strategy use with variables such as learning styles, gender, proficiency level, and culture (Bedell \& Oxford, 1996; Bruen, 2001; Green \& Oxford, 1995; Nyikos \& Oxford, 1993; Oxford \& Burry-Stock, 1995; Wharton, 2000). The current study was designed to correlate language learning strategy use with ASC. Results of the study may provide educational implications to promote language strategy use among learners with different degrees of ASC.

\section{B. Academic Self-concept}

Marsh and Shavelson (1985) defined self-concept as “a person's perceptions of him- or herself.” Byrne (1988) noted that social comparison plays a significant role in the formation of one's self-concept. As noted by Marsh (1986), students may evaluate their performance in a specific subject in relation to their performance in another school subject. However, they may also compare their self-perceptions of performance with the perceived performance of their peers (Capper, Foust, Callahan, \& Albaugh, 2009; Rinn, Plucker, \& Stocking, 2010; Rost, Sparfeldt, Dickhäuser, \& Schilling, 2005). Self-concept is shaped by an individual's experiences and interactions with significant people (Shavelson, Hubner, \& Stanton, 1976). According to the hierarchical model of self-concept posited by Shavelson et al. (1976), selfconcept should be viewed as multidimensional since it is comprised of nonacademic (e.g., social, emotional) and academic (e.g., math, English) components. Marsh and Shavelson (1985) revised the model by proposing two higher order academic factors, math/academic self-concept and verbal/academic self-concept, which are nearly uncorrelated (Marsh, Kong, \& Hau, 2001). The latter can be further broken into different subject domains, including English and foreign language (Marsh, Byrne, Shavelson, 1988).

A number of studies by researchers in different disciplines have demonstrated the correlation between ASC and achievement when subject specific self-concept is matched with achievement in the corresponding area (Drysdale \& Milne, 2006; Hansford \& Hattie, 1982; Liu, 2008; Marsh, Byrne, \& Shavelson, 1988; Marsh, Parker, \& Barnes, 1985; Marsh, Relich, \& Smith, 1983; Marsh \& Yeung, 1998; Muijs, 1997). A reciprocal-effects model, whereby academic self-concept and academic achievement serve as a predictor of one another, is strongly supported by many researchers (De Fraine, Van Damme, \& Onghena, 2007; Marsh, 1990; Marsh, Hau, \& Kong, 2002; Marsh, Trautwein, Lüdtke, Köller, \& Baumert, 2005). Marsh, Hau, and Kong (2002) conducted a large scale six year longitudinal study using Hong Kong high school students as the sample to investigate the relations among academic self-concept, academic achievement, and language of instruction (Chinese and English). The findings provided support for the reciprocaleffects model, although the effects of prior academic self-concept on subsequent related achievement tended to be stronger than the other way around. They concluded that the relation between academic self-concept and academic achievement is reciprocal and "mutually reinforcing" regardless of what language of instruction is used. The improvement of one construct depends on the enhancement of the other; otherwise, the improvement may be a shortterm effect. In another longitudinal causal ordering study conducted by Marsh, Trautwein, Lüdtke, Köller, and Baumert (2005) to examine the relations among academic self-concept, academic interest, and academic achievement, they reached a similar conclusion that academic self-concept can be both a cause and effect of academic achievement. More recently, a new conceptual model posited by Guay, Rateele, Roy, and Litalien (2010) indicated that academic motivation plays an important mediating role in the relation between academic self-concept and achievement. It should be noted that although the academic achievement/self-concept relation has been reported in extensive studies by many researchers, such as Marsh and his colleagues (Marsh et al, 1988; Marsh et al., 2001), few have centered on the relationship between English self-concept and language achievement. 
The operational definition of academic self-concept used in the present study is based on the research of Liu and Wang (2005). In a study that examined gender differences in academic self-concept among Singaporean secondary school learners, they identified students' confidence and effort as two first-order factors of academic self-concept. They defined academic confidence as "student's feelings and perceptions about their academic competence" and academic effort as "students' commitment to, and involvement and interest in schoolwork" (p. 22).

\section{Research Questions}

The present study aims to investigate the strategy use of EFL college students and its relation with their ASC. The major research questions are as follows:

(1) For the full sample, what are the broad profile of overall strategy use, the frequency of strategy use in six categories, and the most and the least used strategy items?

(2) Is there a significant relationship between strategy use and leaner ASC?

(3) Are there significant differences by different degree of positive academic self-concept in terms of overall strategy use, any of the six strategy categories and strategy items?

\section{METHOD}

\section{A. Participants}

The sample was 163 university freshmen, 75 (46\%) males and $88(54 \%)$ females, enrolled in different majors in central Taiwan. They were assigned to different levels of English classes for completing university-wide required English courses according to their GEPT (General English Proficiency Test, an official English proficiency test commissioned by Taiwan Ministry of Education) scores. The same series of teaching materials were used in all of these classes. Participants of the study included three classes of students from each ability level, including basic, intermediate, and advanced levels. They were administered the questionnaires a few weeks after the start of the 2010-2011 academic year.

\section{B. Instruments}

To measure learner strategy use, Oxford's (1990, version 7.0) 50-item version of the Strategy Inventory for Language Learning (SILL), designed for learners of English as a second or foreign language, was used in current study. The SILL has been extensively used and checked for reliability and validity in multiple ways (Oxford and Burry-Stock, 1995). In the present study, reliability of the strategy use questionnaire was measured at .94 using Cronbach's alpha.

The SILL used in the current study consists of 50 items and has been classified into six categories: (a) memory strategy items (items 1 to 9), (b) cognitive strategy items (items 10 to 23), (c) compensation strategy items (items 24 to 29), (d) metacognitive strategy items (items 30 to 38), (e) affective strategy items (items 39 to 44), and (f) social strategy items (items 45 to 50). They are assessed on a five-point Likert scale ranging from 1 to 5 . The number indicates the frequency of strategy use, ranging from 1 (never or almost never) to 5 (always or almost always).

The instrument used to measure student ASC was adapted from Liu, Wang and Parkins's (2005) ASC scale. It is composed of two subscales, the academic confidence subscale ( 9 items) and the academic effort subscale (10 items), to assess students' academic self-confidence and their involvement and interest in schoolwork. Each item was scored on a six-point Likert-type scale, ranging from 1 (strongly disagree) to 6 (strongly agree). The questionnaire demonstrated satisfactory internal reliability, achieving an alpha coefficient of .89. Reliability coefficients for the $\mathrm{AC}$ and $\mathrm{AE}$ subscales were .87 and .83 , respectively. All of the above-mentioned instruments used in the present study were modified and translated by the first author into a Chinese version for use in the study.

\section{Procedures}

To address the first research question, the mean scores for the overall strategy use, the frequency of use of the six strategy categories, and the 50 strategy items were all computed. To investigate the relation between learners' strategy use and ASC, Pearson's product-moment correlation coefficients of all the related variables were obtained and analyzed. Furthermore, the use of language learning strategies among students of different degrees of positive ASC was closely analyzed to address research questions 3 and 4. Before statistical analyses were conducted, subjects were divided into three groups according to their scores on the ASC scale. Multivariate analysis of variance (MANOVA) was performed on (1) the overall strategy scores, (2) the six strategy category scores, and (3) individual item scores to examine the differences in strategy use by students at three different levels of positive ASC. All the negative worded items in the scale were scored in reverse before any of the above statistical analyses were performed.

\section{RESULTS AND DisCUSSION}

\section{A. Strategy Use of the Full Sample}

The means and standard deviations were computed for the use of each of the six strategy categories (see Table 1). According to Oxford's (1990) key to understanding students' mean scores on strategy use, overall the participants of the current study had medium use of language learning strategies (2.8). That is, they "sometimes" used the learning 
strategies (ibid., p.291). Strategies in the compensation, metacognitive, and cognitive categories were the most used types of strategies, while social strategies were the least used, followed by memory strategies.

TABLE 1.

MEANS AND STANDARD DEVIATIONS INDICATING OVERALL STRATEGY USE OF THE FULL SAMPLE

\begin{tabular}{lccc}
\hline Strategy Category & $\begin{array}{c}\text { Rank Order } \\
\text { of Usage }\end{array}$ & Mean \\
\hline Compensation & 1 & 2.90 & .64 \\
Metacognitive & 2 & 2.83 & .70 \\
Cognitive & 3 & 2.81 & .62 \\
Affective & 4 & 2.72 & .68 \\
Memory & 5 & 2.70 & .64 \\
Social & 6 & 2.56 & .75 \\
Overall & & 2.76 & .59 \\
\hline
\end{tabular}

The findings of the current study support findings from previous studies on the EFL language strategy use (LSU) in which compensation strategy category (SC) was the most used SC by EFL learners (Chang, 2010; Lee \& Oxford, 2008; Chen, 2005; Lan \& Oxford, 2003; Mochizuki, 1999; Klassen, 1994).

To identify the most and least frequently used strategy items, the mean of each strategy item was calculated. Descriptive statistics of the five most frequently used and the five least frequently used items are presented in Table 2 and Table 3, respectively. As Table 2 shows, two items scored at the higher end of the medium-use range, namely, items 15 and 10. Both of these strategies were classified in the cognitive categories. Item 15 of watching English TV shows or going to movies in English provides an opportunity for both recreation and learning purposes. It is the most used SI by the research participants. Item 10 asks the learners whether they "say or write new English words several times." The other three most frequently used items $(29,1,32)$ were all in the medium-use range.

TABLE 2.

MEANS AND STANDARD DEVIATIONS OF THE FIVE MOST FREQUENTLY USED LEARNING STRATEGIES

\begin{tabular}{cllcl}
\hline Strategy No. & Strategy & Mean & SD & Strategy Category \\
\hline 15 & $\begin{array}{l}\text { I watch English language TV shows } \\
\text { or go to movies in English. }\end{array}$ & 3.42 & 1.04 & Cognitive \\
10 & $\begin{array}{l}\text { I say or write new English words } \\
\text { several times. }\end{array}$ & 3.37 & .90 & Cognitive \\
$29 \quad \begin{array}{l}\text { If I cannot think of an English word, } \\
\text { I use a word or phrase that means the } \\
\text { same thing. }\end{array}$ & 3.15 & .96 & Compensation \\
1 & $\begin{array}{l}\text { I think of relationships between what I } \\
\text { already know and new things I learn } \\
\text { in English. }\end{array}$ & 3.09 & .85 & Memory \\
32 & $\begin{array}{l}\text { I pay attention when someone is } \\
\text { speaking English. }\end{array}$ & 3.08 & .97 & Metacognitive \\
\hline
\end{tabular}

Table 3 shows the least frequently used learning strategy items, including items 43, 7, 49, 14, and 17. The mean scores ranged from 2.23 to 2.34 . They were all in the low-use range, but mostly in different categories. Participants in the current study presented a reluctant use of affective strategy item 43, likely due to the influence of a cultural component on strategy use. It has been reported that learners of Chinese ethnic background have a disinclination to use affective strategies (Wharton, 2000).

TABLE 3.

MEANS AND STANDARD DEVIATIONS OF THE FIVE LEAST FREQUENTLY USED LEARNING STRATEGIES

\begin{tabular}{rlccc}
\hline Strategy No. & Strategy & Mean & SD & Strategy Category \\
\hline 43 & I write down my feelings in a language & 2.23 & .98 & Affective \\
& learning journal. & & & \\
7 & I physically act out new English words. & 2.26 & .84 & Memory \\
49 & I ask questions in English. & 2.33 & .96 & Social \\
14 & I start conversation in English. & 2.34 & .92 & Cognitive \\
17 & I write notes, messages, letters, or & 2.34 & .98 & Cognitive \\
& reports in English. & & & \\
\hline
\end{tabular}

\section{B. Relationship between Strategy Use and Leaner Academic Self-concept}

To explore the relationships between strategy use and ASC, correlation analysis was performed on the full sample. Finding the predictor relationship will ultimately assist teachers to help students promote strategy use and to use strategies properly. As shown in Table 4, all of the related variables were significantly and positively correlated. The results establish that students with better positive ASC had higher use of strategies in the language learning process. All strategies in the six categories had moderate correlation coefficients with the important affective variable. Among all 
strategy categories, metacognitive and cognitive strategies were consistently found to have the highest correlations with ASC (.646 and .645, respectively), while compensation strategies had the lowest correlation with ASC (.444). It is, therefore, important for language instructors to promote both the use of metacognitive and cognitive strategies to consolidate ASC.

TABLE 4.

CORRElations Between Strategy Use, Motivation, AND ACADEMiC SElF-CONCEPT FOR THE FULl SAMPLE

\begin{tabular}{lccc}
\hline Strategy Category & \multicolumn{3}{c}{ ASC } \\
\cline { 2 - 4 } & Confidence & Effort & Overall \\
\hline Memory & $.503^{* *}$ & $.586^{* *}$ & $.611^{* *}$ \\
Cognitive & $.563^{* *}$ & $.591^{* *}$ & $.646^{* *}$ \\
Compensation & $.412^{* *}$ & $.383^{* *}$ & $.444^{* *}$ \\
Metacognitive & $.509^{*}$ & $.638^{* *}$ & $.645^{* *}$ \\
Affective & $.461^{* *}$ & $.526^{* *}$ & $.554^{* *}$ \\
Social & $.507^{* *}$ & $.564^{* *}$ & $.601^{* *}$ \\
Overall & $.570^{* *}$ & $.636^{* *}$ & $.676^{* *}$ \\
Note. ASC = Academic Self-Concept; Confidence $=$ Academic Confidence; Effort = Academic Effort
\end{tabular}

It should also be noted that both components of ASC, academic confidence and effort, are highly related to overall strategy use. However, among the two components of ASC, effort was more highly related to overall strategy use (.636) than academic confidence (.570). Overall, the correlation between frequency of strategy use and ASC was at the higher end of a medium range (.676).

\section{Differences in LLSU by Different Degree of Positive Academic Self-concept}

In order to more closely examine the strategy use of students who have different degree of positive ASC, subjects were grouped into three ASC levels according to their scores on the ASC scale. Students grouped into the high and low ASC levels accounted for about $25 \%$ on each end of the score distribution while the medium ASC level students accounted for about $50 \%$ of the total score distribution. The means and standard deviations of each of the six strategy categories were calculated for each group and the findings are reported in Table 5.

As shown in Table 5, for those with the most positive ASC, the most often used language strategy was metacognitive strategy $($ mean $=3.35)$. Cognitive and compensation were the next two most frequently used strategies. Compensation strategy was the most often used strategy by students grouped into the medium level (mean $=2.91)$ or low ASC level (mean $=2.52$ ), followed by metacognitive and cognitive strategies.

TABLE 5.

MEANS AND STANDARD DEVIATIONS INDICATING STRATEGy USE OF THE SAMPLE By DifFERENT DEGREE OF POSITIVE ACADEMIC SELF-CONCEPT

\begin{tabular}{|c|c|c|c|c|c|c|}
\hline \multirow[t]{2}{*}{ Strategy Category } & \multicolumn{2}{|c|}{ Low ASC } & \multicolumn{2}{|c|}{ Medium ASC } & \multicolumn{2}{|c|}{ High ASC } \\
\hline & Rank Order & Mean & Rank Order & Mean & Rank Order & Mean \\
\hline Memory & 5 & 2.19 & 4 & 2.74 & 4 & 3.12 \\
\hline Cognitive & 3 & 2.31 & 3 & 2.83 & 2 & 3.27 \\
\hline Compensation & 1 & 2.52 & 1 & 2.91 & 3 & 3.27 \\
\hline Metacognitive & 2 & 2.26 & 2 & 2.86 & 1 & 3.35 \\
\hline Affective & 4 & 2.23 & 5 & 2.72 & 5 & 3.18 \\
\hline Social & 6 & 1.94 & 6 & 2.63 & 6 & 3.07 \\
\hline Overall & & 2.25 & & 2.80 & & 3.22 \\
\hline
\end{tabular}

Multivariate analysis of variance (MANOVA) was performed on (1) the overall strategy scores, (2) the strategy category scores, and (3) individual item scores to investigate whether there were significant differences in strategy use by students at three different levels of perceived ASC (see Table 6). The findings established that differences in either the overall strategy scores or the six categories scores were highly significant among students of different ASC levels. Post hoc tests showed that students with high ASC level had significantly higher frequency of strategy use than those with medium ASC level. Similarly, students with medium ASC level had significantly higher frequency of strategy use than those with low ASC level.

TABLE 6.

MANOVA TEST RESUltS OF DIFFERENCES IN THE STRATEGy SCORES By STUDENTS AT DIFFERENT DEGREE OF POSITIVE ACADEMIC SELF-CONCEPT

\begin{tabular}{lllrrrr}
\hline Source & Dependent Variable & SS & df & MS & F & Sig. \\
\hline ASC & & & & & \\
& Memory & 18.95 & 2 & 9.47 & 31.27 & $.000^{* *}$ \\
& Cognitive & 19.96 & 2 & 9.98 & 38.15 & $.000^{* *}$ \\
& Compensation & 12.13 & 2 & 6.07 & 18.03 & $.000^{* *}$ \\
& Metacognitive & 25.87 & 2 & 12.94 & 38.90 & $.000^{* *}$ \\
& Affective & 19.26 & 2 & 9.63 & 28.02 & $.000^{* *}$ \\
& Social & 28.50 & 2 & 14.25 & 36.34 & $.000^{* *}$ \\
& Overall & 20.53 & 2 & 10.26 & 46.48 & $.000^{* *}$ \\
\hline
\end{tabular}


The most frequently used strategy items for students at different levels of positive ASC are reported in Table 7. Strategy Item (SI) 15 of watching English TV shows and movies and SI 10 of writing new English words several times were the most used strategy items by the research participants. The participants depended on English TV and movies to compensate the lack of native English speakers in the research site, a university located in the rural area in central Taiwan. Repeatedly writing or saying unfamiliar words was the second most used SI among the participants, in line with a study of Korean students who often used this SI to facilitate their English language learning (Lee and Oxford, 2008).

Further analysis of item scores indicated that for students at different levels of positive ASC, the only three items that did not have significant differences included items 15, 26, and 42 (see Table 8). Such lack of significant differences can be recognized by the fact that, for any one of these three items, most participants tended to either employ it or not to employ it in a similar way.

TABLE 7.

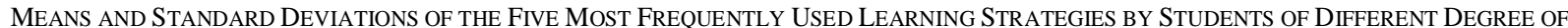
POSITIVE ACADEMIC SELF-CONCEPT

\begin{tabular}{|c|c|c|c|c|c|c|}
\hline $\begin{array}{l}\text { ASC } \\
\text { Level }\end{array}$ & $\begin{array}{l}\text { Strategy } \\
\text { No. }\end{array}$ & Strategy Item & $\begin{array}{l}\text { Rank } \\
\text { Order }\end{array}$ & Mean & $\mathrm{SD}$ & $\begin{array}{l}\text { Strategy } \\
\text { Category }\end{array}$ \\
\hline \multicolumn{7}{|l|}{ Low } \\
\hline & 15 & $\begin{array}{l}\text { I watch English language TV shows } \\
\text { spoken in English or go to movies } \\
\text { spoken in English. }\end{array}$ & 1 & 3.28 & 1.10 & Cognitive \\
\hline & 10 & $\begin{array}{l}\text { I say or write new English words } \\
\text { several times. }\end{array}$ & 2 & 3.21 & 1.17 & Cognitive \\
\hline & 42 & $\begin{array}{l}\text { I notice if I am tense or nervous when } \\
\text { I am studying or using English. }\end{array}$ & 3 & 2.84 & 1.27 & Affective \\
\hline & 24 & $\begin{array}{l}\text { To understand unfamiliar English } \\
\text { words, I make guesses. }\end{array}$ & 4 & 2.77 & .92 & Compensation \\
\hline & 28 & $\begin{array}{l}\text { I try to guess what the other person will } \\
\text { say next in English. }\end{array}$ & 5 & 2.74 & 1.03 & Compensation \\
\hline & 29 & $\begin{array}{l}\text { If I can't think of an English word, I use } \\
\text { a word or phrase that means the same } \\
\text { thing. }\end{array}$ & 5 & 2.74 & 1.16 & Compensation \\
\hline \multicolumn{7}{|c|}{ Medium } \\
\hline & 15 & $\begin{array}{l}\text { I watch English language TV shows } \\
\text { spoken in English or go to movies } \\
\text { spoken in English. }\end{array}$ & 1 & 3.35 & 1.05 & Cognitive \\
\hline & 10 & $\begin{array}{l}\text { I say or write new English words } \\
\text { several times. }\end{array}$ & 2 & 3.29 & .76 & Cognitive \\
\hline & 29 & $\begin{array}{l}\text { If I can't think of an English word, I use } \\
\text { a word or phrase that means the same } \\
\text { thing. }\end{array}$ & 3 & 3.15 & .80 & Compensation \\
\hline & 32 & $\begin{array}{l}\text { I pay attention when someone is } \\
\text { speaking English. }\end{array}$ & 4 & 3.11 & .84 & Metacognitive \\
\hline & 12 & I practice the sounds of English. & 5 & 3.11 & .75 & Cognitive \\
\hline \multicolumn{7}{|l|}{ High } \\
\hline & 15 & $\begin{array}{l}\text { I watch English language TV shows } \\
\text { spoken in English or go to movies } \\
\text { spoken in English. }\end{array}$ & 1 & 3.67 & .94 & Cognitive \\
\hline & 10 & $\begin{array}{l}\text { I say or write new English words } \\
\text { several times. }\end{array}$ & 1 & 3.67 & .78 & Cognitive \\
\hline & 32 & $\begin{array}{l}\text { I pay attention when someone is } \\
\text { speaking English. }\end{array}$ & 2 & 3.65 & .65 & Metacognitive \\
\hline & 12 & I practice the sounds of English. & 3 & 3.63 & .87 & Cognitive \\
\hline & 24 & $\begin{array}{l}\text { To understand unfamiliar English } \\
\text { words, I make guesses. }\end{array}$ & 4 & 3.60 & .69 & Compensation \\
\hline & 38 & $\begin{array}{l}\text { I think about my progress in learning } \\
\text { English. }\end{array}$ & 4 & 3.60 & .73 & Metacognitive \\
\hline & $\begin{array}{l}29 \\
\text { a word or }\end{array}$ & $\begin{array}{l}\text { If I can't think of an English word, I use } \\
\text { hrase that means the same } \\
\text { thing. }\end{array}$ & 5 & 3.53 & .85 & Compensation \\
\hline
\end{tabular}

TABLE 8.

\begin{tabular}{clcccc}
\multicolumn{7}{c}{ MEANS OF STRATEGY ITEMS THAT DID NOT SHOW SIGNIFICANT DIFFERENCES } \\
\hline Strategy No. & Strategy & $\mathrm{M}$ & $\mathrm{F}$ & Sig. & $\begin{array}{l}\text { Strategy } \\
\text { Category }\end{array}$ \\
\hline 15 & $\begin{array}{l}\text { I watch English language TV shows } \\
\text { spoken in English or go to movies } \\
\text { spoken in English. }\end{array}$ & 1.88 & 1.76 & .18 & Cognitive \\
26 & $\begin{array}{l}\text { I make up new words if I do not know } \\
\text { the right ones in English. }\end{array}$ & 1.84 & 1.95 & .15 & Compensation \\
& $\begin{array}{l}\text { I notice if I am tense or nervous when } \\
\text { I am studying or using English. }\end{array}$ & 1.60 & 1.76 & .18 & Affective \\
\hline
\end{tabular}




\section{CONCLUSION}

The current study revealed that ASC is highly and positively correlated with LLSU of all six strategy categories. Significant relationship between 50 language learning strategy items and ASC was also detected while only three particular SIs indicated no significance with ASC. The compensation strategy category is the most used SC and social is the least. Compensation strategies are much needed for learners to overcome any gaps in the knowledge of the target language (TL) (Oxford, 1990; Magno, 2010) and enable learners to guess the unfamiliar TL items they encountered (Yang, 2007). The positive relationship between ASC and LLSU revealed in this study encourages English instructors to provide positive stimulation to learners to consolidate their TL learning regardless their previous English learning experience or outcome.

It is important that language instructors strive to develop students' own metacognition which will facilitate them to choose the most appropriate strategies for a given task (Chamot, 2004). It is important for learners to learn specific strategy items that have been identified in research. They need to learn how to use strategies that are found to be effective for the tasks they are required to accomplish and sustain in their TL.

\section{ACKNOWLEDGEMENT}

We are very grateful to Da-Yeh University for funding this research project under the contract no. ORD-9964. We would also like to thank the instructors who generously helped us collect the data during their classes and all the students who were willing to participate in the study.

\section{REFERENCES}

[1] Allwright, D. (1990). Autonomy in language pedagogy. CRILE Working Paper 6. Center for Research in Education, Lancaster, U.K.: University of Lancaster.

[2] Bedell, D.A., \& Oxford, R.L. (1996). Cross-cultural comparisons of language learning strategies in the People's Republic of China and other countries. In R. L. Oxford (Ed.), Language learning strategies around the world: Cross-cultural perspectives (pp. 47-60). Honolulu, HI: University of Hawaii Press.

[3] Bruen, J. (2001). Strategies for success: Profiling the effective learner of German. Foreign Language Annals, 34(3), $216-225$.

[4] Byrne, B. M. (1988). Adolescent self-concept, ability grouping and social comparison: Reexamining academic track differences in high school. Youth \& Society, 20(1), 46-67.

[5] Byrne, B. M. (1990). Self-concept and academic achievement: Investigating their importance as discriminators of academic track membership in high school. Canadian Journal of Education, 15(2), 173-182.

[6] Capper, M. R., Foust, R. C., Callahan, C. M., \& Albaugh, S. B. (2009). Grade and gender differences in gifted students' selfconcepts. Journal for the Education of the Gifted, 32(3), 340-367.

[7] Chamot, A. U. (2008). Strategy instruction and good language learners. In C. Griffiths (Ed.), Lessons from Good Language Learners, 266-281. Cambridge, UK: Cambridge University Press.

[8] Chamot, A. U. (2005). Language learning strategy instruction: current issues and research. Annual Review of Applied Linguistics, 25, 112-130.

[9] Chamot, A. U. (2004). Issues in language learning strategy research and teaching. Electronic Journal of Foreign Language Teaching, 1(1), 14-26.

[10] Chamot, A.U., Barnhardt, S., El-Dinary, P.B., \& Robbins, J. (1999). The learning strategies handbook. White Plains, NY: Addison Wesley Longman.

[11] Chang, C. (2010). Language learning strategy profile of English as foreign language learners in Taiwan: A comparative case study. Crane Publishing Co., Ltd.

[12] Chen, C. S. (2005). Relationship between non-native English speaking EFL pre-service teachers' English language learning strategies and believes toward teaching methodologies. Unpublished Ph.D. dissertation. The Pennsylvania State University.

[13] Choi, N. (2005). Self-efficacy and self-concept as predictors of college students' academic performance. Psychology in the Schools, 42(2), 197-205.

[14] Cohen, A. D. \& Weaver, S. J. (2006). Styles and strategies-based instruction: A teachers' guide. Minneapolis, MN: Center for Advanced Research on Language Acquisition, University of Minnesota.

[15] Cohen, A.D., Weaver, S., \& Li, T-Y. (1998). The impact of strategies-based instruction on speaking a foreign language. In A.D. Cohen, Strategies in learning and using a second language, 107-156. London: Longman.

[16] De Fraine, B., Van Damme, J., \& Onghena, P. (2007). A longitudinal analysis of gender differences in academic self-concept and language achievement: A multivariate multilevel latent growth approach. Contemporary Educational Psychology, 32(1), $132-150$.

[17] Drysdale, M. T. B., \& Milne, S. (2006). Gender differences in math and verbal self-concept and the impact on academic achievement. (ERIC Document Reproduction Services: No. ED 490 612)

[18] Ehrman, M., Leaver, B. \& Oxford, R. L. (2003). A brief overview of individual differences in second language learning. System, 31, 313-330.

[19] Ehrman, M. \& Oxford, R. L. (1989). Effects of sex differences, career choice, and psychological type on adult language learning strategies. Modern Language Journal, 73(1), 1-13.

[20] Ehrman, M. \& Oxford, R. L. (1990). Adult language learning styles and strategies in an intensive training setting. Modern Language Journal, 74(3), 311-327.

[21] Ellis, R. (1994). Understanding second language acquisition. New York: Oxford University Press. 
[22] Green, J. M. \& Oxford, R. L. (1995). A closer look at learning strategies, L2 proficiency, and gender. TESOL Quarterly, 29, 261-297.

[23] Griffiths, C. (2003). Patterns of language learning strategy use. System, 31, 367-383.

[24] Guay, F., Ratelle, C. F., Roy, A., \& Litalien, D. (2010). Academic self-concept, autonomous academic motivation, and academic achievement: Mediating and additive effects. Learning and Individual Differences, 20, 644-653.

[25] Hansford, B. C., \& Hattie, J. A. (1982). The relationship between self and achievement/performance measures. Review of Educational Research, 52(1), 123-142.

[26] Hsiao, T. Y. \& Oxford, R. L. (2002). Comparing theories of language learning strategies: A confirmatory factor analysis. Modern Language Journal, 86(3), 368-383.

[27] Klassen, J. (1994). The language learning strategies of freshman English students in Taiwan: A case study. Unpublished MA thesis, California State University at Chico, CA

[28] Lan, R., \& Oxford, R. L. (2003). Language learning strategy profiles of elementary school students in Taiwan. IRAL, 41, 339379.

[29] Lee, K. R. \& Oxford, R. (2008). Understanding EFL Learners' Strategy Use and Strategy Awareness. Asian EFL Journal, 10(1), 7-32.

[30] Little, D. (1991). Learner autonomy 1: definitions, issues, and problems. Dublin: Authentik.

[31] Liu, H. J. (2008). The relationship between EFL student academic self-concept and language performance. Feng Chia Journal of Humanities and Social Sciences, 17, 165-184.

[32] Liu, W. C., \& Wang, C. K. J. (2005). Academic self-concept: A cross-sectional study of grade and gender differences in a Singapore secondary school. Asia Pacific Education Review, 6(1), 20-27.

[33] Liu, W. C., Wang, C. K. J., \& Parkins, E. J. (2005). A longitudinal study of students' academic self-concept in a streamed setting: The Singapore context. British Journal of Educational Psychology, 75, 567-586.

[34] Magno, C. (2010). Korean students' language learning strategies and years of studying of English as predictor of proficiency in English, TESOL Journal, 2, 39-61.

[35] Marsh, H. W. (1986). Verbal and math self-concepts: An internal/external frame of reference model. American Educational Research Journal, 23(1), 129-149.

[36] Marsh, H. W. (1990). Causal ordering of academic self-concept and academic achievement: A multiwave, longitudinal panel analysis. Journal of Educational Psychology, 82(4), 646-656.

[37] Marsh, H. W., Byrne, B. M., \& Shavelson, R. J. (1988). A multifaceted academic self-concept: Its hierarchical structure and its relation to academic achievement. Journal of Educational Psychology, 80, 366-380.

[38] Marsh, H. W., Hau, K.-T., \& Kong, C.-K. (2002). Multilevel causal ordering of academic self-concept and achievement: Influence of language of instruction (English compared with Chinese) for Hong Kong students. American Educational Research Journal, 39(3), 727-763.

[39] Marsh, H. W., Kong, C.-K., \& Hau, K.-T. (2001). Extension of the internal/external frame of reference model of self-concept formation: Importance of native and nonnative languages for Chinese students. Journal of Educational Psychology, 93(3), 543553.

[40] Marsh, H. W., Parker, J., \& Barnes, J. (1985). Multidimensional adolescent self-concepts: Their relationship to age, sex and academic measures. American Educational Research Council, 22(3), 422-444.

[41] Marsh. H. W., Relich, J. D., \& Smith, I. D. (1983). Self-concept: The construct validity of interpretations based upon the SDQ Journal of Personality and Social Psychology, 45(1), 173-187.

[42] Marsh, H. W., \& Shavelson, R. J. (1985). Self-concept: Its multifaceted, hierarchical structure. Educational Psychologist, 20(3), 107-123.

[43] Marsh, H. W., Trautwein, U., Lüdtke, O., Köller, O., \& Baumert, J. (2005). Academic self-concept, interest, grades, and standardized test scores: Reciprocal effects models of causal ordering. Child Development, 76(2), 397-416.

[44] Marsh, H. W., \& Yeung, A. S. (1998). Longitudinal structural equation models of academic self-concept and achievement: Gender differences in the development of math and English constructs. American Educational Research Journal, 35, 705-738.

[45] Mochizuki, A. (1999). Language learning strategies used by Japanese university students. RELC Journal, 30(2), 101-113.

[46] Muijs, R. D. (1997). Predictors of academic achievement and academic self-concept: A longitudinal perspective. British Journal of Educational Psychology, 67, 263-277.

[47] Naiman, N., Frohlich, M., Stern, H. H. \& Todesco, A. (1978). The good language learner. Toronto, Canada: The Ontario Institute for Studies in Education.

[48] Nyikos, M. \& Oxford, R. L. (1993). A factor-analytic study of language-learning strategy use: Interpretations from information processing and social psychology. Modern Language Journal, 77, 11-22.

[49] Olivares-Cuhat, G. (2002). Learning strategies and achievement in the Spanish writing classroom: A case study. Foreign Language Annals, 35(5), 561-570.

[50] O’Malley, J. M., \& Chamot, A. U. (1990). Learning strategies in second language acquisition. Cambridge: Cambridge University Press.

[51] O'Malley, J. M,, Chamot, A. U., Stewner-Manzanares, G., Kupper, L. \& Russo, R. P. (1985). Learning strategies used by beginning and intermediate ESL students. Language Learning, 34, 21-46.

[52] Oxford, R. L. (1993). Instructional implications of gender differences in second/foreign language (L2) learning styles and strategies. Applied language learning, 4, 65-94.

[53] Oxford, R. L. (1990). Language learning strategies: What every teacher should know. Boston: Heinle and Heinle.

[54] Oxford, R. L. (Ed.) (1996). Language learning strategies around the world: Cross-cultural perspectives, University of Hawaii Press.

[55] Oxford, R. L. \& Burry-Stock, J. A. (1995). Assessing the use of language learning strategies worldwide with the ESL/EFL version of the strategy inventory for language learning (SILL). System, 23, 1-23. 
[56] Oxford, R. L. \& Ehrman, M. E. (1995). Adults' language learning strategies in an intensive foreign language program in the United States. System, 23, 359-386.

[57] Oxford, R. L. \& Nyikos, M. (1989). Variables affecting choice of language learning strategies by university students. Modern Language Journal, 73(2), 291-300.

[58] Park, G. (1997). Language learning strategies and English Proficiency in Korean University students. Foreign Language Annals, 30(2), 211-221.

[59] Rinn, A. N., Plucker, J. A., \& Stocking, V. B. (2010). Fostering gifted students' affective development: A look at the impact of academic self-concept. Teaching Exceptional Children Plus, 6(4), 2-13.

[60] Rost, D. H., Sparfeldt, J. R., Dickhäuser, O., \& Schillnig, S. R. (2005). Dimensional comparisons in subject-specific academic self-concepts and achievements: A quasi-experimental approach. Learning and Instruction, 15, 557-570.

[61] Rubin, J., Chamot, A. U., Harris, V. \& Anderson, N. (2007). Intervening in the use of the strategies. In A. D. Cohen \& E. Macaro (Eds.). Language learner strategies: 30 years of research and practice, 141-160. Oxford, England: Oxford University Press.

[62] Rubin, J. (1975). What the "good language learner" can teach us. TESOL Quarterly, 9, 41-51.

[63] Rubin, J. (1981). Study of cognitive processes in second language learning. Applied Linguistics, 2, 117-131.

[64] Shavelson, R. J., Hubner, J. J., \& Stanton, G. C. (1976). Self-concept: Validation of construct interpretations. Review of Educational Research, 46, 407-441.

[65] Stern, H. H. (1975). What can we learn from the good language learner? Canadian Modern Language Review, 34, $304-318$.

[66] Wharton, G. (2000). Language learning strategy use of bilingual foreign language learners in Singapore. Language Learning, 50(2), 203-243.

[67] Yang, M. N. (2007). Language learning strategies for junior college students in Taiwan: Investigating ethnicity and proficiency. Asian EFL Journal, 9(2), 35-57.

Hui-ju Liu is an assistant professor in the Department of English at Da-Yeh University in Taiwan. She has a Ph.D. degree in Educational Psychology from the University of Minnesota. Her research interests include ability grouping and individual diffe rences in foreign language learning. Her current publications focus on topics related to academic self-concept, motivation, and learner anxiety.

Chih-hui Chang received her Ph.D. from Department of Educational Studies at University of York, U.K. Her thesis was on second language acquisition and learning. She taught advanced ESL speaking and writing classes at Northern Virginia Community College in the USA and now is the head of Department of English at Da-Yeh University in Taiwan. Her research interest is on language learning strategy use. She currently devotes most of her time in running service-leaning implemented courses of teaching English to underprivileged elementary school pupils in rural area of central Taiwan. 